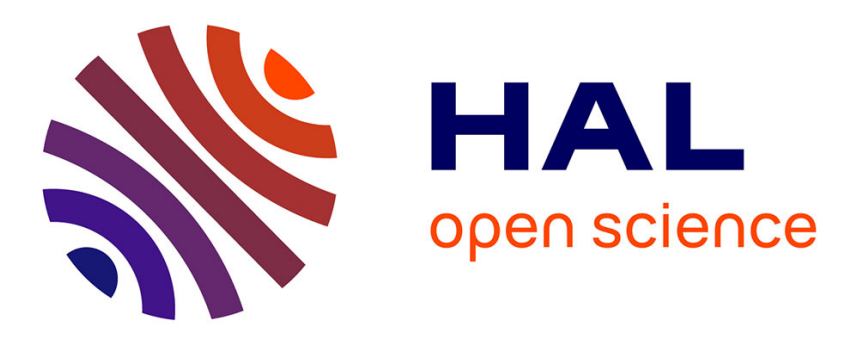

\title{
Alkylphenolic compounds and bisphenol A contamination within a heavily urbanized area: case study of Paris.
}

Mathieu Cladière, Johnny Gasperi, Catherine Lorgeoux, Céline Bonhomme, Vincent Rocher, Bruno Tassin

\section{To cite this version:}

Mathieu Cladière, Johnny Gasperi, Catherine Lorgeoux, Céline Bonhomme, Vincent Rocher, et al.. Alkylphenolic compounds and bisphenol A contamination within a heavily urbanized area: case study of Paris.. Environmental Science and Pollution Research, 2013, 20 (5), pp.2973- 2983. 10.1007/s11356012-1220-6 . hal-00756694

\section{HAL Id: hal-00756694 \\ https://hal-enpc.archives-ouvertes.fr/hal-00756694}

Submitted on 23 May 2018

HAL is a multi-disciplinary open access archive for the deposit and dissemination of scientific research documents, whether they are published or not. The documents may come from teaching and research institutions in France or abroad, or from public or private research centers.
L'archive ouverte pluridisciplinaire HAL, est destinée au dépôt et à la diffusion de documents scientifiques de niveau recherche, publiés ou non, émanant des établissements d'enseignement et de recherche français ou étrangers, des laboratoires publics ou privés. 


\section{Alkylphenols compounds and bisphenol A contamination within a heavily urbanized area: case study of Paris}

Cladiere, Mathieu ${ }^{1 *}$; Gasperi, Johnny ${ }^{1}$; Lorgeoux, Catherine ${ }^{1}$; Bonhomme, Céline ${ }^{1}$; Rocher, Vincent $^{2}$; Tassin, Bruno ${ }^{1}$.

${ }^{1}$ : Université Paris-Est, LEESU, UMR MA 102 - AgroParisTech, 61 avenue du Gal de Gaulle, 94010 Créteil Cedex.

${ }^{2}$ : SIAAP, Direction du Développement et de la Prospective, 82 avenue Kléber, 92700 Colombes.

Corresponding author*: Mathieu.cladiere@leesu.enpc.fr

This study aims at evaluating the influence of a heavily urbanized area such as the Paris city area on receiving water contamination by bisphenol A (BPA) and alkylphenol ethoxylate by-product (APE). Firstly, concentrations in urban sources were investigated. Therefore, in addition to wastewater treatment plant effluents commonly studied, wet-weather urban sources including combined sewer overflows, urban runoff and total atmospheric fallout were considered. The first results highlight significant contaminations of all urban sources (from few ng/L in atmospheric fallout to several $\mu \mathrm{g} / \mathrm{L}$ in other sources) with clearly distinguishable distribution patterns. Secondly, the concentration changes along the Seine River from upstream to downstream of Paris conurbation were investigated. While concentrations of BPA and nonylphenoxy acetic acid $\left(\mathrm{NP}_{1} \mathrm{EC}\right)$ significantly increase because of urban sources, 4-nonylphenol concentrations are homogeneous along the Seine River. These results suggest a global dissemination of 4nonylphenol at the scale of the Seine River basin. Finally, the relationship between pollutant concentrations and Seine river flow were studied upstream and downstream of the Parisian conurbation. As a result, the clear decrease of $\mathrm{NP}_{1} \mathrm{EC}$ dissolved concentrations according to Seine River flow underlines the influence of punctual urban pollution on Seine River contamination. Conversely, 4-nonylphenol dissolved concentrations reinforce the hypothesis of its widespread at the scale of the Seine River basin.

Keywords: Nonylphenol, bisphenol A, urban sources, Seine River, atmospheric fallout, heavily urbanized area 


\section{Introduction}

Among the pollutants commonly pointed out in the literature for their endocrine disrupting properties, alkylphenol ethoxylates (APE) and the 2,2-(4,4 hydroxydiphenyl) propane commonly named bisphenol A (BPA) deserve special attention because of their global spread in the environment (Staples et al. 1998; Vethaak et al. 2005). APE, mainly composed of nonylphenol ethoxylate (NPE: 80\%) and octylphenol ethoxylate (OPE: 20\%), are widely used for industrial and domestic applications, such as lubricating, oil additives, detergents and antistatic agents (Ying et al. 2002). A reasonable estimate of the world annual production of NPE is around 500,000 tons (Ying et al. 2002). BPA is mainly used as a monomer in the manufacture of polycarbonate plastics known for its high resistance to shocks and temperature (plastic windows or greenhouses, car bumpers, baby bottles), and in epoxy resins used as food contact lacquer for cans and tin cans. Due to its uses, the world production of BPA was evaluated at about 3,000,000 tons (Vandenberg et al. 2007)

While BPA is recognized as an endocrine disrupting chemical (Wetherill et al. 2007), NPE and OPE have been of rising concern because of their biodegradation by-products. Indeed, in urban or natural environment NPE can be biodegraded through oxidative or non-oxidative pathways (John and White 1998; Jonkers et al. 2001). Under oxidative biodegradation pathway, NPE turn into carboxylic acids such as nonylphenol acetic acid $\left(\mathrm{NP}_{1} \mathrm{EC}\right)$ while under non-oxidative biodegradation pathway, short chain ethoxylates are produced such as nonylphenol diethoxylate $\left(\mathrm{NP}_{2} \mathrm{EO}\right)$ and nonylphenol monoethoxylate (NP $\left.\mathrm{N}_{1} \mathrm{EO}\right)$ (Giger et al. 2009). Finally, $\mathrm{NP}_{1} \mathrm{EC}$ and $\mathrm{NP}_{1} \mathrm{EO}$ can be biodegraded into 4-nonylphenol (4-NP) known as the most toxic and persistent by-products of NPE in the aquatic environment (Servos 1999).

The occurrence of APE and BPA in environment is closely correlated with anthropogenic activities. Many studies suggest that these chemicals preferentially enter into the environment through urban sources (Sharma et al. 2009; Ying et al. 2002). Among the urban sources investigated in the literature, the effluents of wastewater treatment plants (WWTP) are frequently studied (Hohne and Puttmann 2008; Loyo-Rosales et al. 2007; Voutsa et al. 2006; Zhou et al. 2010). On the contrary, studies on wet weather urban sources such as combined sewer overflows (CSOs) and urban runoff are less available, despite their high contamination (Björklund et al. 2009; Gasperi et al. 2008).

The Seine Basin, located in North-West part of France, drains approximately a 32,000 $\mathrm{km}^{2}$ area from its headwaters to Paris. It can be considered as representative of river basins exposed to the impacts of intense human activity (Parisian conurbation: 12 million of inhabitants, among the thirty most populous cities in the world and the third in Europe after Moscow and London) (Meybeck et al. 2007). This basin combines strong anthropogenic pressures with a very limited dilution factor in the Seine River, due to its low flow rate (Seine River median flow at Paris: $350 \mathrm{~m}^{3} / \mathrm{s}$ ). Actually, no comprehensive data on the occurrence of APE and BPA are presently available for the upper part of the Seine basin. As far as we are aware, only few studies deal with the influence of such heavily urbanized conurbations (more than 10 millions of 
inhabitants) on their environment (Isobe et al. 2001) and none of them focus on watershed of European cities.

As a consequence, the study tackles several objectives. The first objective is to assess the occurrence of APE and BPA concentrations and their relative significance in different urban sources of the Parisian conurbation such as the effluents of the major WWTP, the main CSO outfall and urban runoff. Secondly, this study aims at evaluating the influence of the Parisian conurbation on receiving water between upstream and downstream sampling sites. Finally, the last objective is to better examine the concentration variation of target compounds according to the hydrological conditions on upstream and downstream sites.

\section{Materials and methods}

\section{Sampling sites / campaigns}

Seine River water was collected at three locations ( $\mathrm{n}=11$ for each sampling location; Table 1) from February 2010 to February 2011. The first site, Marnay, is located upstream of the Parisian conurbation (weakly urbanized). The second site, Bougival, is located just downstream of Paris City (heavily urbanized). Finally, the last site, Meulan, is located downstream of all Parisian wastewater effluent discharges (heavily urbanized) (Fig. 1). In addition, the Orgeval River in an agricultural experimental catchment (Vilain et al. 2012) was also monitored during year 2011 $(\mathrm{n}=9)$ (Fig. 1). All samples were manually collected in $2 \mathrm{~L}$ glass amber bottles previously pyrolysed at $500^{\circ} \mathrm{C}$ to avoid sample contaminations.

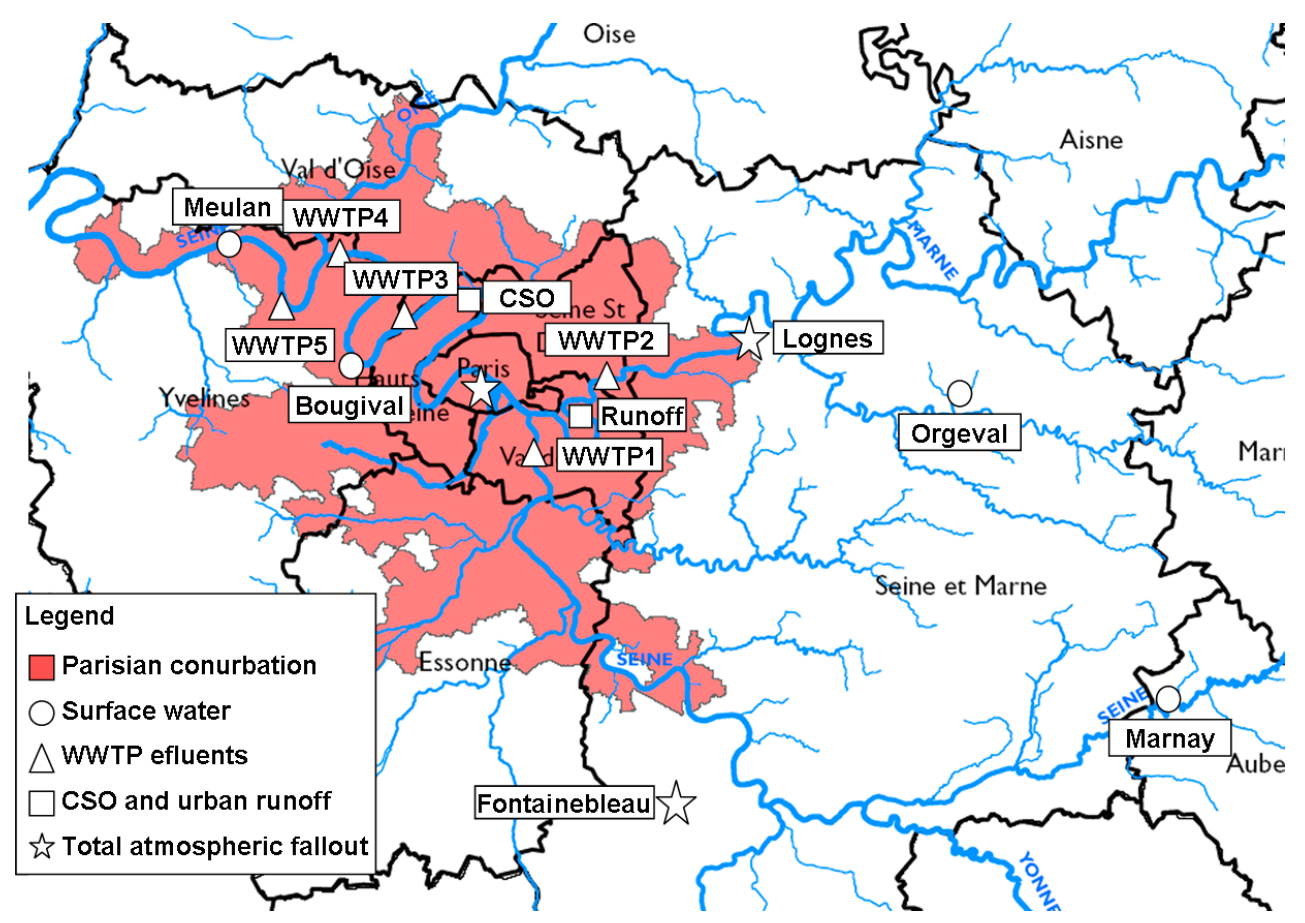

Fig. 1 Sampling sites within the Parisian conurbation 
Urban sources investigated include WWTP effluents, total atmospheric fallout (TAF), urban runoff and CSOs. For WWTP effluents, the effluents of the 5 major WWTPs (WWTP1 to WWTP5 on Fig. 1) of the Parisian conurbation were monitored monthly from January 2011 to November 2011 $(n=9)$. These WWTPs are supervised by the Parisian public sanitation service (SIAAP) and treat more than 2 millions $\mathrm{m}^{3}$ of wastewater every day (70\% of the Parisian conurbation inhabitants). Samples were collected in $2 \mathrm{~L}$ glass amber bottles also pyrolysed at $500^{\circ} \mathrm{C}$. Among these five WWTPs, three different processes of wastewater treatment are considered. Firstly, the WWTP1 use conventional activated sludge (AS) for carbon and nitrogen removal (AS-WWTP), WWTP4 use activated sludge for carbon removal and biofiltration (B) for nitrogen removal (ASB-WWTP), finally the more recent WWTP2, WWTP3 and WWTP5 use biofiltration units for both carbon and nitrogen removals (B-WWTP). The removal efficiencies on organic matter (evaluated with the Chemical Oxygen Demand: COD) and nitrogen (nitrification: Total Kjeldahl Nitrogen (TKN), denitrification: total nitrogen (TN)) are disclosed in Table 1. According to these efficiencies, WWTP1,2,3 and 5 reveal high removals for organic matter and nitrogen. Conversely, WWTP4 which is the largest WWTP of the Parisian conurbation and one of the biggest in the world (more than $1,600,000 \mathrm{~m}^{3}$ of wastewater treated every day) highlights lower efficiencies for organic matter (COD: 85\%), nitrogen (TKN: 70\%; TN: 20\%) and SS (90\%). Measures for the modernization of this WWTP are under way to improve its efficiency for carbon and nitrogen removals.

Table 1 sampling site characteristics

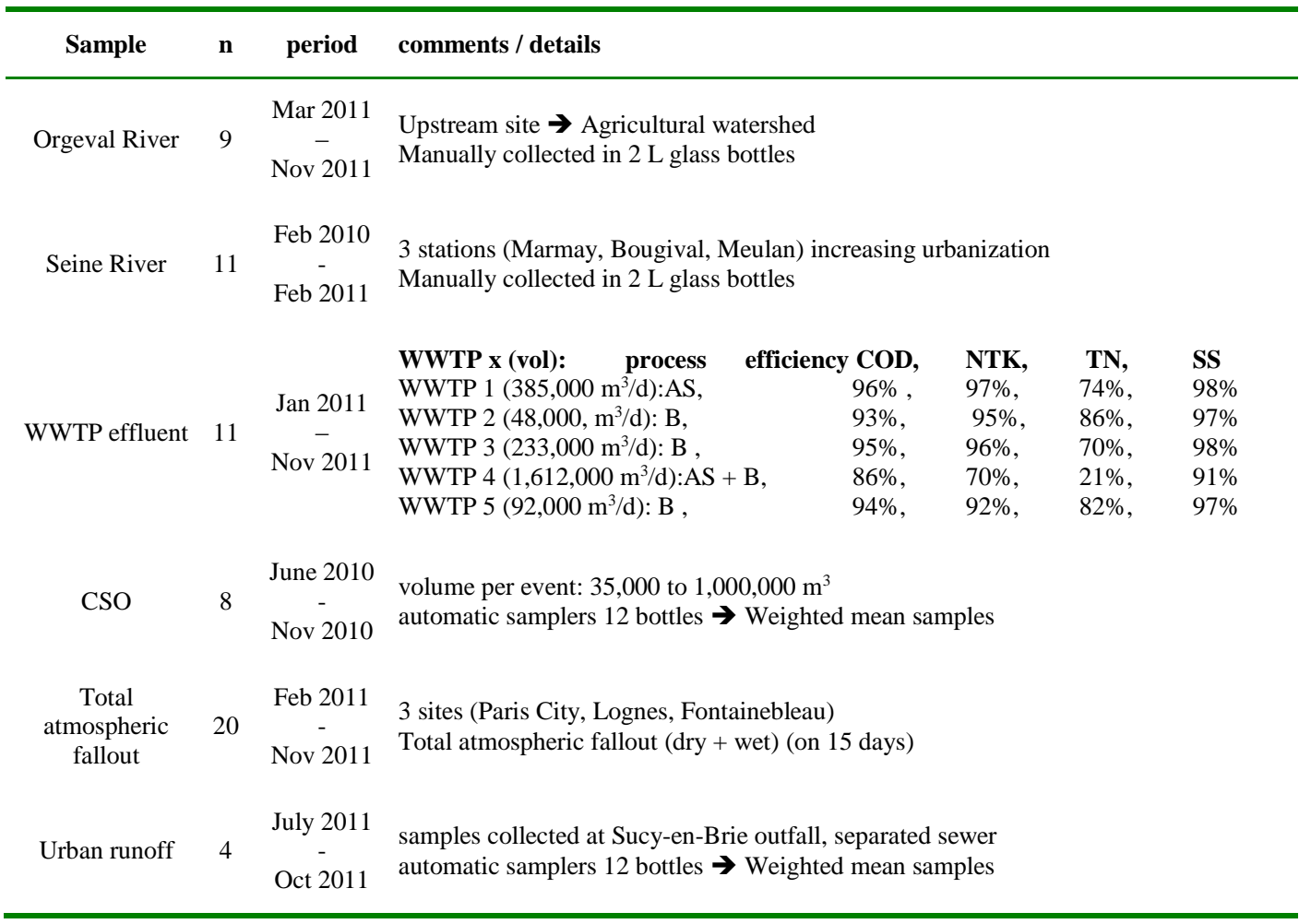

In addition to WWTP effluents, urban sources during wet weather period were also sampled, i.e. combined sewer overflows (CSOs) and urban runoff in separate sewer. CSOs were sampled at Clichy outfall, one of the biggest outfalls of the Parisian conurbation, for 8 events (discharged 
volumes ranging from $35,000 \mathrm{~m}^{3}$ to more than 1,000,000 $\mathrm{m}^{3}$ ) (Fig. 1). Urban runoff was sampled at the outlet of small sub-urban catchment (Sucy-en-Brie) for 4 rain events (Fig. 1). For CSOs and runoff, samplings were performed by an automatic sampler. Flow-weighted composite samples representative of the entire discharges were considered for analyse. At last, TAF were collected at Paris city (heavily urbanized; $n=10$ ), Lognes (weakly urbanized; $n=5$ ) and at the Fontainebleau forest $(n=5)$ in $10 \mathrm{~L}$ glass bottles fitted with $1 \mathrm{~m}^{2}$ aluminium funnels (Fig. 1) during 7 periods (15 days) between January and November 2011.

\section{Analytical procedure}

\section{Sample preparation}

Bisphenol A (BPA), 4-nonylphenol (4-NP), nonylphenol mono- and diethoxylate ( $\left.\mathrm{NP}_{1 \& 2} \mathrm{EO}\right)$, nonylphenol acetic acid ( $\left.\mathrm{NP}_{1} \mathrm{EC}\right)$, 4-tert-octylphenol (4-t-OP) and octylphenol mono- and diethoxylate $\left(\mathrm{OP}_{1 \& 2} \mathrm{EO}\right)$ were analyzed in dissolved and SS. After filtration (GF/F, Whatman), $100 \mathrm{~mL}$ of dissolved phase for CSOs or $250 \mathrm{~mL}$ for all other water samples were spiked with a surrogate standard mixture (BPA-d6, $\mathrm{NP}_{1} \mathrm{EO}-\mathrm{d} 2$, OP-d17) before extraction.

For dissolved phase, samples were extracted by solid phase extraction (Autotrace SPE Workstation, Caliper LifeScience) using OASIS ${ }^{\circledR}$ HLB cartridges $(200 \mathrm{mg}, 6 \mathrm{~mL})$. After conditioning with $10 \mathrm{~mL}$ of methanol and $10 \mathrm{~mL}$ of ultrapure water, dissolved samples were extracted at $5 \mathrm{~mL} / \mathrm{min}$, under neutral $\mathrm{pH}$. After drying, elutions were performed with $12 \mathrm{~mL}$ of a mixture methanol (MeOH)/Dichloromethane (DCM)/Ethyl acetate (Etace) (40/40/20, v/v).

After freeze-drying, the SS were extracted by microwave assisted extraction using a multiwave 3000 (Antonn Paar). The filters, were extracted using $20 \mathrm{~mL}$ of $\mathrm{MeOH} / \mathrm{DCM}$ $(60 / 40, \mathrm{v} / \mathrm{v})$ mixture at $100^{\circ} \mathrm{C}$ and 7 bars during $30 \mathrm{~min}$. After extraction, samples were cleaned up by SPE using OASIS ${ }^{\circledR}$ HLB $(200 \mathrm{mg}, 6 \mathrm{~mL}$ ). Basically, after conditioning ( $3 \mathrm{~mL} \mathrm{MeOH}$ and $3 \mathrm{~mL}$ $\mathrm{MeOH} / \mathrm{H}_{2} \mathrm{O}(20 / 80 \mathrm{v} / \mathrm{v})$, the samples dissolved in $500 \mu \mathrm{L}$ of $\mathrm{MeOH} / \mathrm{H}_{2} \mathrm{O}(50 / 50 \mathrm{v} / \mathrm{v})$ mixture, were deposited on the top of the cartridges. Then, the cartridges were washed with $3 \mathrm{~mL}$ of $\mathrm{H}_{2} \mathrm{O}$ prior to elution with $9 \mathrm{~mL}$ of $\mathrm{MeOH} / \mathrm{DCM} / \mathrm{Etace}(40 / 40 / 20, \mathrm{v} / \mathrm{v} / \mathrm{v})$ mixture.

\section{UPLC-MS-MS analysis}

Before analysis, both extracts were concentrated and spiked with internal standard for quantification (BPA-d16, n-NP and $\mathrm{n}-\mathrm{NP}_{1} \mathrm{EO}$ ). The analysis was performed by liquid chromatography coupled to a tandem mass spectrometry, LC-MS-MS (AQUITY UPLC / TQD, Waters). APEOs and BPA were separated on an AQUITY UPLC / BEH C 18 column, heated at 40 ${ }^{\circ} \mathrm{C}$, with ultrapure water (A) and methanol (B) each containing $4.5 \mathrm{mM} \mathrm{NH} 4 \mathrm{OH}$. Equilibration takes place with $50 \% \mathrm{~B}$ at $0.4 \mathrm{~mL} / \mathrm{min}$ and $10 \mu \mathrm{L}$ of sample were injected. The mass spectrometer is equipped with an electrospray interface used in positive ionization mode (ESI+) for $\mathrm{NP}_{1 \& 2} \mathrm{EO}$ and $\mathrm{OP}_{1 \& 2} \mathrm{EO}$ and negative ionization mode (ESI-) for all other compounds. The compounds were detected in multiple reactions monitoring mode (MRM) with two mass transitions. 


\section{Analytical variability}

In order to assess the variability of the analytical protocol, three surface water samples from the same sampling location (downstream of WWTP 4) were individually analyzed. This variability was only studied for the dissolved phase extraction and UPLC-MS-MS analysis and not for the suspended solids. Actually, in receiving water, alkylphenols and BPA are mostly present in the dissolved phase (4-NP: 80\%; 4-t-OP: 90\% and BPA: 95\%; Cladiere et al. 2010; Isobe et al. 2001). The dissolved phases of the three water samples were extracted in triplicates and each extraction was also analyzed in triplicates. Thus, nine concentration values were obtained for each sample and every target compound. The nine values were compared to the median in order to calculate relative deviations that are representative of the analytical variability. Finally, the absolute values of relative deviations generated for the three samples $(9 \times 3=27)$ were represented on Fig. 2 as histograms for BPA, 4-NP and NP $\mathrm{NEC}_{1}$
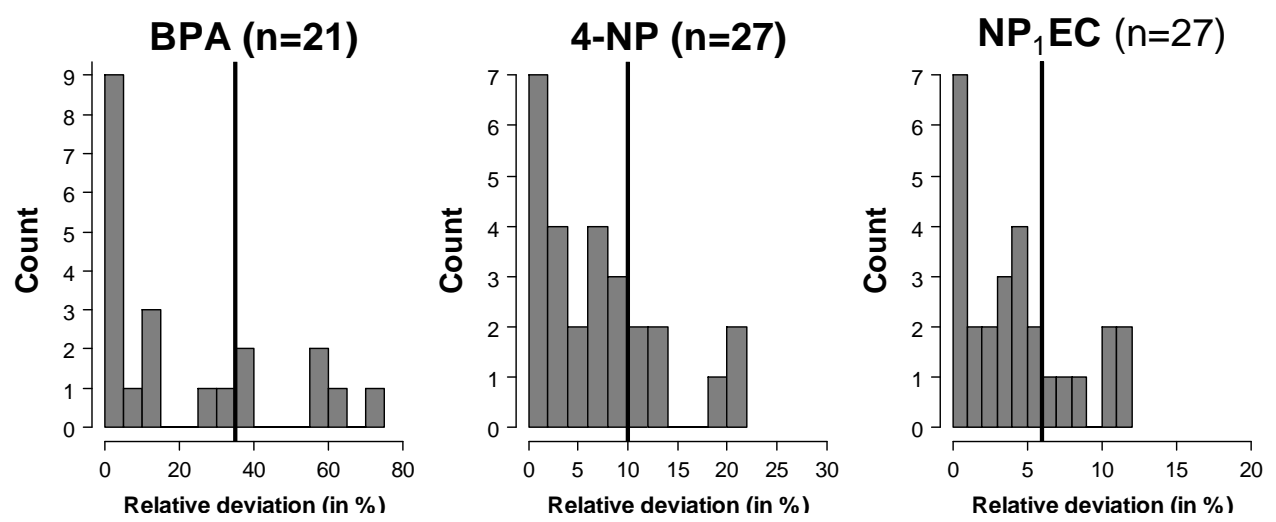

Fig. 2 Distribution histograms of relative deviations of $\mathrm{BPA}$, 4-NP, and $\mathrm{NP}_{1} \mathrm{EC}$ to the median value. The bold lines represent the third quartile of the relative deviations.

For 4-NP, $\mathrm{NP}_{1} \mathrm{EC}$ and $\mathrm{NP}_{2} \mathrm{EO}$, the relative deviations globally lie within the $0-15 \%$ range while maximum values reach $20 \%$ for 4 -NP. Thus, in order to account $75 \%$ of the relative deviation values (bold lines), the analytical variabilities $( \pm \mathrm{AV})$ of $4-\mathrm{NP}, \mathrm{NP}_{1} \mathrm{EC}$ and $\mathrm{NP}_{2} \mathrm{EO}$ were respectively estimated at $10 \%, 6 \%$ and $13 \%$. For $\mathrm{BPA}$ and $\mathrm{NP}_{1} \mathrm{EO}$, the relative deviations were calculated only for 21 analyses since their concentrations were close to their limit of quantification (LOQ: BPA: $11 \mathrm{ng} / \mathrm{L}$; NP ${ }_{1} E O: 10 \mathrm{ng} / \mathrm{L}$ ). Similarly to previous compounds and in order to account $75 \%$ of the relative deviation values (bold lines), the analytical variabilities of BPA and $\mathrm{NP}_{1} \mathrm{EO}$ were respectively evaluated at $35 \%$ and $31 \%$. For OPE, the analytical variabilities were not evaluated since these compound concentrations were mostly under their limit of quantification (4-t-OP: $4 \mathrm{ng} / \mathrm{L} ; \mathrm{OP}_{1} \mathrm{EO}: 12 \mathrm{ng} / \mathrm{L}$ and $\mathrm{OP}_{2} \mathrm{EO}: 3 \mathrm{ng} / \mathrm{L}$ ) in investigated surface water.

\section{Data exploitation}

The concentrations presented in this study are total concentrations (expressed in $\mathrm{ng} / \mathrm{L}$ ) calculated by summing dissolved concentrations (ng/L) and SS concentrations (ng/L). For the variations of concentrations with hydrological conditions, only the dissolved phase was considered in order to better assess the origins of target compounds (punctual or diffuse sources) within the Seine River. 
Results are displayed in box plots which extend from the 1st quartile (Q1) to the 3rd quartile (Q3) and thus contain the central half of the distribution score. Dotted lines symbolize 1.5 times the interquartile range while outliers are indicated as points above or below the dotted lines.

Since concentration distributions of each sampling point cannot be assumed to be normally distributed; non parametric tests were performed to compare concentrations found on different sites. The Wilcoxon signed-rank test was selected to compare the Marnay, Bougival and Meulan sites since samplings were collected on the same day at the three sites. For the same reason, the Wilcoxon signed-rank test was also used to compare the WWTP effluents. For all other matrices and sampling sites (TAF, CSO, runoff and Orgeval), the Mann-Whitney U test was selected to compare distributions of different sizes. In accordance with the analytical variabilities, statistical significance was accepted at $\mathrm{p}<0.1$ for all comparisons.

\section{Results and discussions}

\section{Urban sources}

\section{Wastewater treatment plants}

Results found in WWTP effluents for BPA and NPE are illustrated in Fig. 3. Three groups corresponding to AS-WWTP, ASB-WWTP and B-WWTP as described earlier are considered.
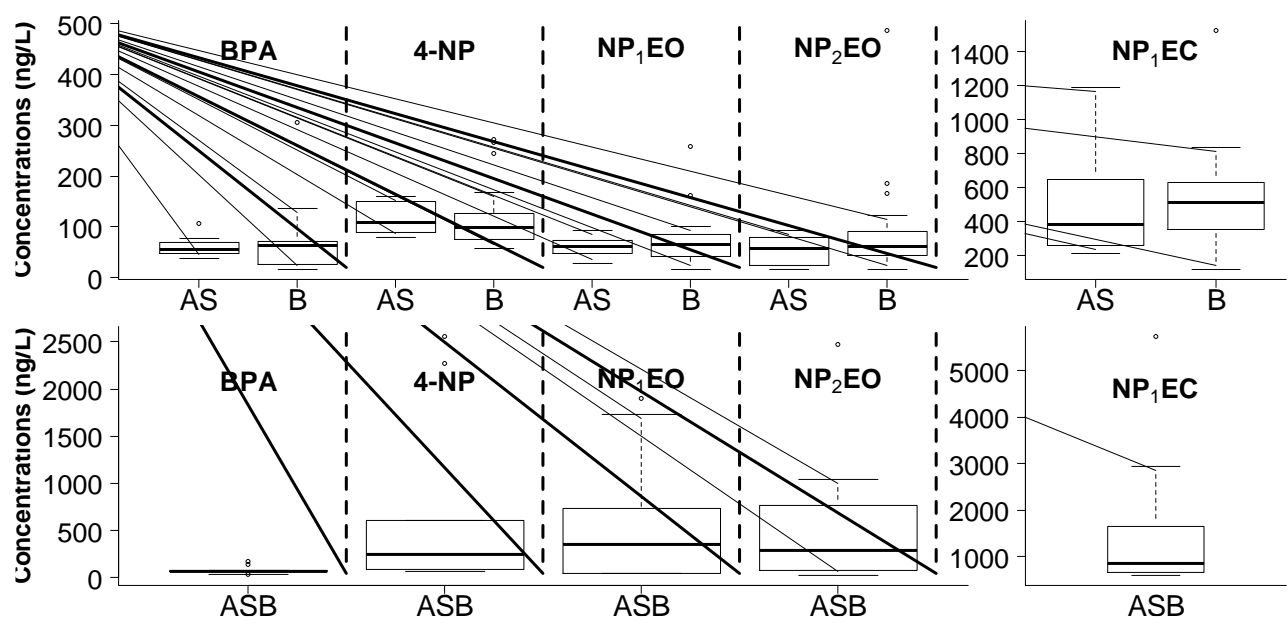

Fig. 3 Concentrations of target compounds (ng/L) in WWTP effluents. AS: activated sludges; B: biofiltration; ASB: activated sludge (carbon removal) + biofiltration (nitrogen removal)

For AS-WWTP and B-WWTP considered, the median concentrations $( \pm \mathrm{AV})$ of effluents were evaluated at $67( \pm 24) \mathrm{ng} / \mathrm{L}$ for BPA, $114( \pm 12) \mathrm{ng} / \mathrm{L}$ for $4-\mathrm{NP}, 74( \pm 23) \mathrm{ng} / \mathrm{L}$ for $\mathrm{NP}_{1} \mathrm{EO}$, 74( \pm 9$) \mathrm{ng} / \mathrm{L}$ for $\mathrm{NP}_{2} \mathrm{EO}$ and $573( \pm 34) \mathrm{ng} / \mathrm{L}$ for $\mathrm{NP}_{1} \mathrm{EC}$. For ASB-WWTP (WWTP4) the median concentrations $( \pm \mathrm{AV})$ found in the effluent were higher and evaluated at $76( \pm 27) \mathrm{ng} / \mathrm{L}$ for BPA, 244( \pm 24$) \mathrm{ng} / \mathrm{L}$ for 4-NP, 304( \pm 109$)$ for $\mathrm{NP}_{1} \mathrm{EO}, 295( \pm 38) \mathrm{ng} / \mathrm{L}$ for $\mathrm{NP}_{2} \mathrm{EO}$ and $861( \pm 62) \mathrm{ng} / \mathrm{L}$ for $\mathrm{NP}_{1}$ EC. The OPE were less concentrated $(<54 \mathrm{ng} / \mathrm{L})$ and only account for $10 \%$ of target alkylphenols in accordance with their use distributions (Ying et al. 2002). Globally, these median 
concentrations are similar to those reported in the literature in Europe (Hohne and Puttmann 2008; Jonkers et al. 2009), USA (Loyo-Rosales et al. 2007), China (Zhou et al. 2010) and in a previous study in the Parisian conurbation (Gilbert et al. 2012).

The WWTP effluents were characterized by the predominance of NPE (4-NP and $\mathrm{NP}_{1} \mathrm{EC}$ ) comparatively to BPA. The low concentrations of BPA in WWTP effluents (medians being 76( \pm 27$) \mathrm{ng} / \mathrm{L}$ for ASB-WWTP and 67( \pm 24$) \mathrm{ng} / \mathrm{L}$ for B-WWTP and AS-WWTP) result from the high efficiency of wastewater treatment and the high BPA biodegradation during wastewater treatment processes (about 90\% according to Zhou et al. (2010)). Concerning NPE, the main byproduct of nonylphenol ethoxylate surfactants found in all WWTP effluents is $\mathrm{NP}_{1} \mathrm{EC}$, median concentrations being $861( \pm 39) \mathrm{ng} / \mathrm{L}$ for ASB-WWTP and $512( \pm 31) \mathrm{ng} / \mathrm{L}$ for B-WWTP and ASWWTP. The $\mathrm{NP}_{1} \mathrm{EC}$ has already been claimed as the major by-product of NPE during wastewater treatment processes essentially based on aerobic biodegradation (Ahel et al. 1994). In contrast to results reported by Loyo-Rosales et al. (2007), but in accordance with those quoted by Hohne and Puttmann (2008) no seasonal trend of concentrations could be drawn for all WWTP effluents from January 2011 to November 2011.

By comparing the AS-WWTP and B-WWTP effluents (Wilcoxon signed-rank test), no significant differences of concentrations appear for all target compounds ( $p>0.1)$. The ASB-WWTP effluent does not exhibit any statistical difference compared to AS-WWTP and B-WWTP effluent for BPA and 4-NP $(\mathrm{p}>0.1)$. Conversely, for NPE by-product $\left(\mathrm{NP}_{1} \mathrm{EC}, \mathrm{NP}_{1} \mathrm{EO}\right.$ and $\left.\mathrm{NP}_{2} \mathrm{EO}\right)$ significant differences were found between ASB-WWTP and AS-WWTP + B-WWTP effluents $(\mathrm{p}<0.05)$. The higher concentrations found in ASB-WWTP effluents can be certainly explained by the lower biodegradation rate on organic and nitrogenous matter (COD: 86\%, NTK: 70\%, TN: $21 \%$ ) and to a lesser extent by the higher concentration of SS $(23 \mathrm{mg} / \mathrm{L}$ for WWTP4, against 5 and $10 \mathrm{mg} / \mathrm{L}$ for other WWTPs).

\section{Urban sources during wet weather period}

Concentrations found in CSOs, runoff and TAF are exhibited in Table 2.

Table 2 Total atmospheric fallout, CSO and runoff concentrations (ng/L)

\begin{tabular}{cccc}
\hline Compound & $\begin{array}{c}\text { TAF n=20 (ng/L) } \\
\text { min-max (median) }\end{array}$ & $\begin{array}{c}\text { CSO n=8 (ng/L) } \\
\text { min }-\max (\text { median) }\end{array}$ & $\begin{array}{c}\text { Runoff n=4 (ng/L) } \\
\text { min }-\max (\text { mean) }\end{array}$ \\
\hline BPA & $10-180(40)$ & $917-2098(1410)$ & $287-1224(635)$ \\
\hline $4-\mathrm{NP}$ & $<\mathrm{LQ}^{1}-167(80)$ & $445-1208(668)$ & $272-533(400)$ \\
$\mathrm{NP}_{1} \mathrm{EO}$ & $<\mathrm{LQ}^{1}-65(21)$ & $357-1257(598)$ & $47-401(184)$ \\
$\mathrm{NP}_{2} \mathrm{EO}$ & $<\mathrm{LQ}^{1}-301(10)$ & $138-401(250)$ & $146-847(402)$ \\
$\mathrm{NP}_{1} \mathrm{EC}$ & $2-63(15)$ & $220-591(251)$ & $193-426(128)$ \\
\hline
\end{tabular}

: <LQ: lower than limit of quantification

The concentrations reported in the Table 2 disclose significant differences between TAF, on the one hand, and CSOs and runoff on the other hand ( $<<0.01)$. For example, while concentrations of BPA range between $10( \pm 4)$ and $180( \pm 63) \mathrm{ng} / \mathrm{L}$ in TAF, concentrations vary between 917 and $2098 \mathrm{ng} / \mathrm{L}$ (about 32 times higher) in CSOs and between 287 and $1224 \mathrm{ng} / \mathrm{L}$ (about 13 times 
higher) in runoff. In addition, changes of pattern are clearly noticeable in Table 2. Indeed, while 4$\mathrm{NP}$ has the highest median concentration in TAF $(80( \pm 8) \mathrm{ng} / \mathrm{L})$, BPA is the predominant compound in CSOs and runoff (CSO: $1410( \pm 495) \mathrm{ng} / \mathrm{L}$; runoff: $635( \pm 222) \mathrm{ng} / \mathrm{L})$.

TAF concentrations are generally low. Minimal concentrations are lower or close to the limits of quantification whereas median concentrations are always lower than $100 \mathrm{ng} / \mathrm{L}$ (Table 2). The non parametric Mann-Whitney $U$ test, performed for the three sampling locations, points out that the concentrations of BPA are statistically greater in Paris (heavily urbanized) and in Lognes (weakly urbanized) than in Fontainebleau (forest) while no significant difference between the three sites is found for NPE.

Higher concentrations in CSOs and runoff compared to those measured in TAF highlight a clear enrichment from atmosphere to catchment outlet. These enrichments could originate from wastewater for CSOs or road and buildings leaching (Björklund et al. 2009; Bressy et al. 2011) for runoff since NPE and BPA are used in building material (concrete, plastics). For both CSOs and runoff, the concentrations measured were close to those reported in untreated wastewaters (Zhou et al. 2010). These high concentrations underline necessity to treat wet weather effluents such as CSOs and runoff in order to avoid short-term pollutions of receiving water during wet weather periods especially for BPA.

Comparing CSOs and urban runoff, BPA, 4-NP and $\mathrm{NP}_{1} \mathrm{EO}$ revealed significant differences of concentrations while $\mathrm{NP}_{1} \mathrm{EC}$ and $\mathrm{NP}_{2} \mathrm{EO}$ concentrations were statistically equivalent. Although these results suggest that the wastewater contained in CSOs may play a role in 4-NP, BPA and $\mathrm{NP}_{1} \mathrm{EO}$ concentrations, no correlation could be drawn between wastewater proportion and total concentrations of compounds in CSOs $\left(\mathrm{R}^{2}<0.25\right.$ for all investigated compounds). However, a good correlation between maximum flows discharged by CSOs $\left(\mathrm{Q}_{\max }: \mathrm{m}^{3} . \mathrm{s}^{-1}\right)$ and particulate contents could be drawn for all target compounds $\left(\mathrm{R}^{2} \approx 0.80\right)$. The higher the $\mathrm{Q}_{\max }$, the higher the particulate contents. These results may confirm the existence of in-sewer sources such as sewer deposit erosion during high-intensity events. For some events, Gasperi et al. (2010) demonstrated that in-sewer deposit erosion can actually play a major role in the polycyclic aromatic hydrocarbon or suspended solid contaminations of CSOs.

\section{Surface water}

\section{Concentration change in relation to urbanization gradient}

In order to track the influence of urban sources (WWTPs, CSOs and runoff) on the Seine River, the dissolved organic carbon (DOC) concentrations in Marnay, Bougival and Meulan were analysed in addition to target compounds. As expected, whatever the measurement campaign, a significant increase of DOC concentrations was noticed between Marnay (median: $2.0 \mathrm{mgC} / \mathrm{L}$ ), Bougival (2.8 mgC/L) and Meulan (3.3 mgC/L) (Wilcoxon signed-rank test; $\mathrm{p}<0.05)$.

At the scale of all investigated sites, the concentrations ranged from $<11 \mathrm{ng} / \mathrm{L}$ to $154( \pm 54) \mathrm{ng} / \mathrm{L}$ for BPA, from $28( \pm 3) \mathrm{ng} / \mathrm{L}$ to $157( \pm 16) \mathrm{ng} / \mathrm{L}$ for $4-\mathrm{NP}$ and from $2.1( \pm 0.1) \mathrm{ng} / \mathrm{L}$ to $274( \pm 16) \mathrm{ng} / \mathrm{L}$ for $\mathrm{NP}_{1} \mathrm{EC}$. These concentrations found in surface water within the Parisian conurbation were similar to concentrations reported in Europe (Brix et al. 2010; Jonkers et al. 2010), but lower than 
in the Seine River estuary (4-NP: $168 \mathrm{ng} / \mathrm{L}$ and $\mathrm{NP}_{1} \mathrm{EC}: 544 \mathrm{ng} / \mathrm{L}$; Cailleaud et al. 2007). Concerning the upstream sites Orgeval (representative of rivers not influenced by urban activities) and Marnay (weakly urbanized) the concentrations of target compounds generally lie close to concentrations found in TAF. As a result, these sites could be considered as representative of the background pollution of the Seine River basin by target compounds. Moreover, the environmental quality standards established by the directive 2008/105/EC (European commission 2008) (4-NP: $300 \mathrm{ng} / \mathrm{L}$; 4-t-OP: $100 \mathrm{ng} / \mathrm{L}$ ) were never exceeded in the Seine River since the highest concentrations found in Meulan (the most impacted site) were $157 \mathrm{ng} / \mathrm{L}$ for 4-NP and $30 \mathrm{ng} / \mathrm{L}$ for 4-t-OP

Total concentrations are represented according to the urbanization gradient (from agricultural site to heavily urbanized areas) on Fig. 4.

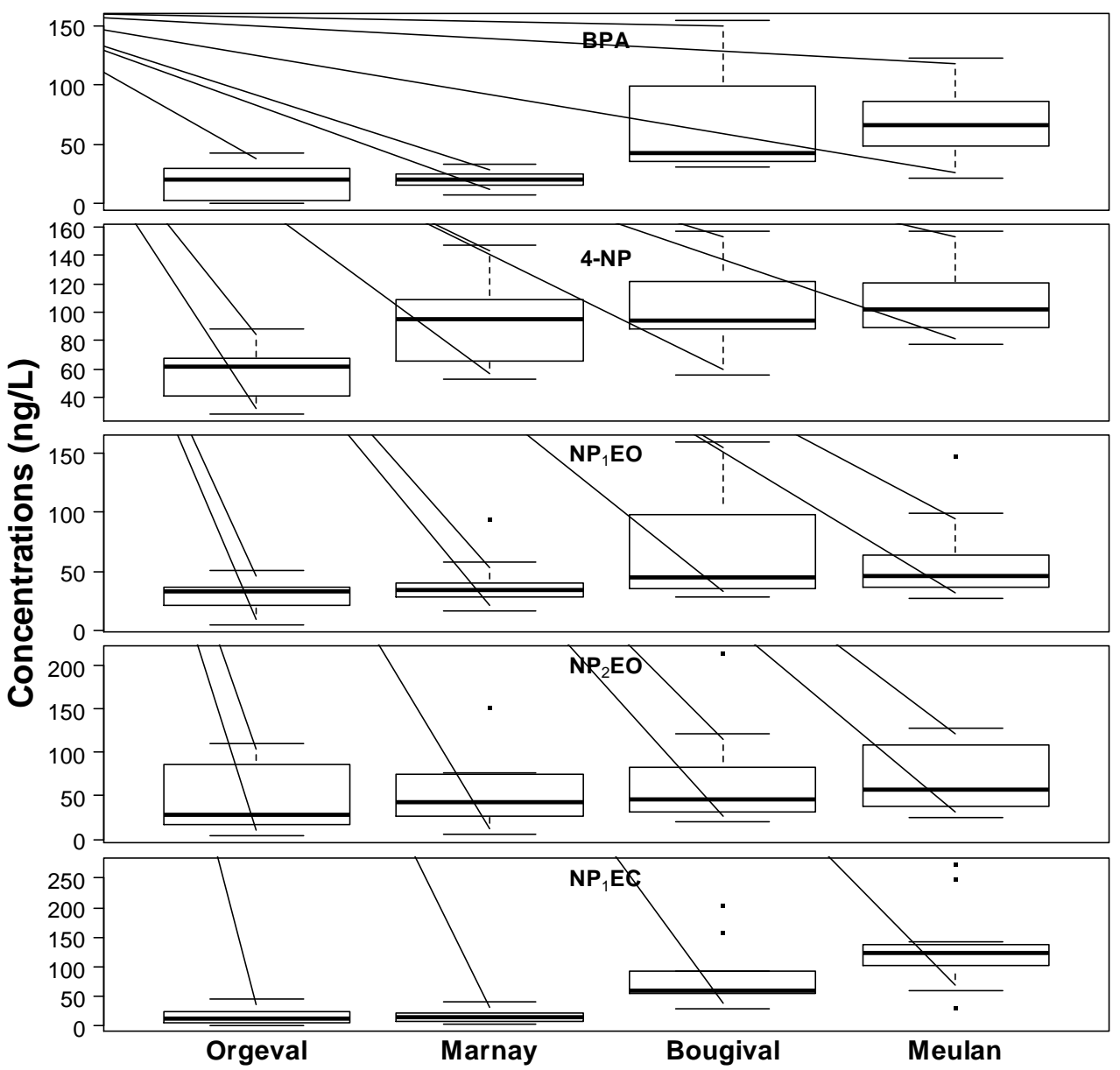

Fig. 4 Change of NPE and BPA concentrations according to urbanization gradient

Three groups of compounds may be distinguished.

In the first group including $\mathrm{BPA}$ and $\mathrm{NP}_{1} \mathrm{EC}$, significant differences $(\mathrm{p}<0.05)$ of concentrations between upstream sites (medians at Orgeval and Marnay: BPA: 20( \pm 7$)$ ng/L; NP $\left.{ }_{1} \mathrm{EC}: 16( \pm 1) \mathrm{ng} / \mathrm{L}\right)$ and downstream sites (Bougival and Meulan BPA: 66( \pm 23$) \mathrm{ng} / \mathrm{L} ; \mathrm{NP}_{1} \mathrm{EC}: 124( \pm 7) \mathrm{ng} / \mathrm{L}$ ) are noticed (Fig. 4). A similar evolution of $\mathrm{NP}_{1} \mathrm{EC}$ concentrations from upstream to downstream stations of the Glatt River have been pointed out by Jonkers et al. (2009). These significant differences underline the influence of urban sources on receiving water for BPA and $\mathrm{NP}_{1} \mathrm{EC}$. 
However, while Bougival and Meulan sites exhibit similar concentrations of BPA, a significant difference could be noticed for $\mathrm{NP}_{1} \mathrm{EC}$ between both sites $(\mathrm{p}<0.05)$. This difference is linked to the large volume discharged by WWTP4 coupled with high concentrations of NP ${ }_{1} \mathrm{EC}$ (median: $861 \pm 51 \mathrm{ng} / \mathrm{L}$ ). Thus, whereas the $\mathrm{NP}_{1} \mathrm{EC}$ was the lowest $\mathrm{NPE}$ by-product in upstream sites, it becomes predominant at Meulan. Similarly, the prevalence of $\mathrm{NP}_{1} \mathrm{EC}$ on a large range of organic pollutants in the Danube River has been reported by Loos et al. (2010).

The second group of compounds $\left(\mathrm{NP}_{1} \mathrm{EO}\right.$ and $\left.\mathrm{NP}_{2} \mathrm{EO}\right)$ reveals no significant difference of concentrations between all sites ( $\mathrm{NP}_{1} \mathrm{EO}: 45( \pm 14) \mathrm{ng} / \mathrm{L}$ and $\left.\mathrm{NP}_{2} \mathrm{EO}: 50( \pm 6) \mathrm{ng} / \mathrm{L}\right)$. The concentrations found in the Orgeval River (agricultural basin) are statistically similar to those found at Meulan site $(\mathrm{p}>0.5)$. A large variation of $\mathrm{NP}_{1} \mathrm{EO}$ concentrations is observable at Bougival site (min: 20( \pm 6$) \mathrm{ng} / \mathrm{L}$; max: 213( \pm 66$) \mathrm{ng} / \mathrm{L}$ ) (Fig. 4). The highest concentrations found at Bougival could be the consequence of the activities generated by Gennevilliers Harbour (the greatest of Île-de-France) located upstream of the sampling site.

Finally, the last group (4-NP and 4-t-OP) reveals a contrasted pattern. A significant difference $(\mathrm{p}<0.05)$ of concentrations between Orgeval River (agricultural basin) and Seine River sites (Marnay, Bougival and Meulan) could be noticed on Fig. 4. The occurrence of 4-NP in the Orgeval River (median: 61( \pm 6$) \mathrm{ng} / \mathrm{L}$ ) could be imputed either to mixture of diffuse sources such as TAF (median: $80( \pm 8) \mathrm{ng} / \mathrm{L}$ ) and groundwater (Latorre et al. 2003), and/or to agricultural activities (Zgola-Grzeskowiak et al. 2009). Conversely, Marnay site could be partially impacted by urban sources and by biodegradation of precursors $\left(\mathrm{NP}_{1} \mathrm{EC}, \mathrm{NP}_{1 \& 2} \mathrm{EO}\right)$ into 4-NP along the Seine River. Nonetheless, no statistical difference between Marnay (weakly urbanized), Bougival and Meulan (heavily urbanized) sites could be drawn $(p>1)$. This homogeneity of concentrations along the Seine River suggests that urban sources are probably not predominant sources of 4-NP on receiving water. Thus, diffuse sources such as TAF, groundwater and biodegradation of 4-NP precursors could play a key role in the occurrence of 4-NP in the environment and the homogeneity of its concentrations along the Seine River. This observation is in agreement with a previous study reporting the same observation on the Glatt River in Switzerland (Jonkers et al. 2009).

The concentrations found in the Seine River are far lower than concentrations leading to an acute lethal effect on aquatic wildlife (lethal concentration (LC50) for rosy barb: $344 \mu \mathrm{g} / \mathrm{L}$; Bhattacharya et al. 2008). However, these authors have claimed that concentration closer to those reported in the Seine River could lead to histopathological effects on gills, liver and kidney of the same fish. In addition Brian et al. (2007) have highlighted the mixture effects of 4-NP, 4-t-OP and BPA. They have reported that the mixture of these three compounds has a greater estrogenic effect on fish's reproduction than each compound separately. Therefore, even the low concentrations found in the Seine River may have chronic effects en aquatic wildlife.

\section{Variation of pollutant concentrations according to hydrological conditions}

The dissolved concentrations of $\mathrm{BPA}, 4-\mathrm{NP}$ and $\mathrm{NP}_{1} \mathrm{EC}$ measured at Marnay and Meulan were compared to the Seine River flow on the Fig. 5. During the sampling period, from February 2010 to February 2011, the Seine River flow ranged from 13 to $228 \mathrm{~m}^{3} / \mathrm{s}$ at Marnay and from 157 to 
$1050 \mathrm{~m}^{3} / \mathrm{s}$ at Meulan. Only the dissolved phase was investigated since the distributions of BPA and NPE between dissolved and particulate phases are mostly in favour of the dissolved phase as previously mentioned. The prevalence of the dissolved phase could be imputed to the low SS concentrations in the Seine River (from $6 \mathrm{mg} / \mathrm{L}$ to $20 \mathrm{mg} / \mathrm{L}$ at Meulan). Furthermore, and depending on the group of compounds, the relationship between the dissolved concentrations and the Seine River flow enables to better understand the origins (spot or diffuse sources) of NPE and BPA in the Seine River.

a) Marnay
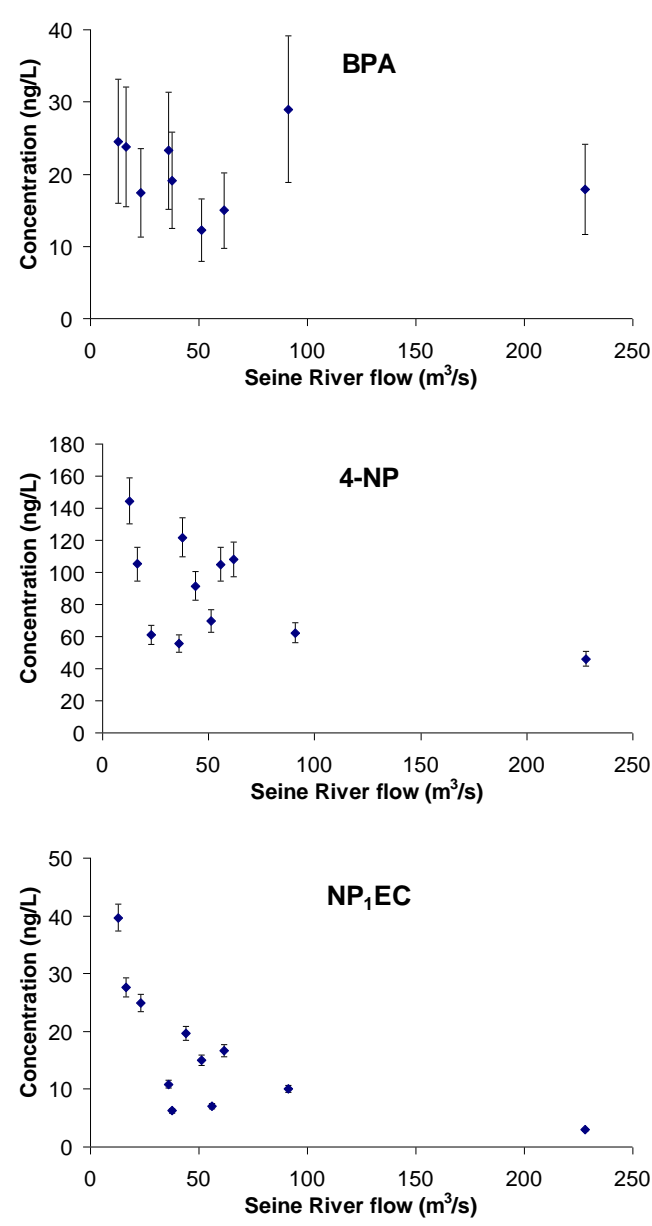

b) Meulan
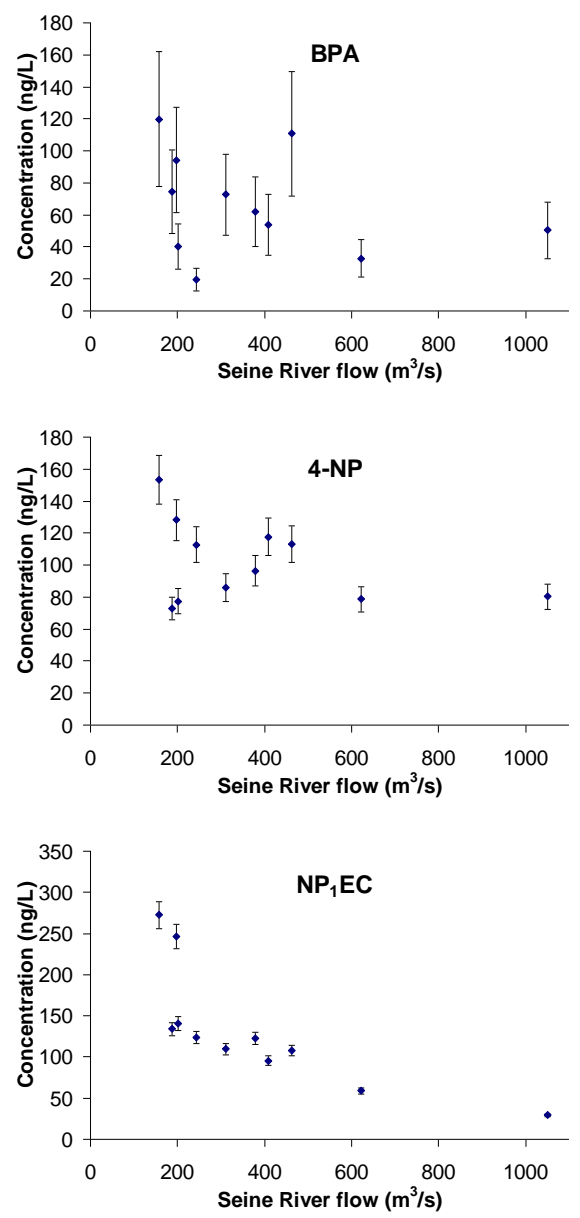

Fig. 5 Dissolved concentrations of target compounds (ng/L) versus Seine River flow $\left(\mathrm{m}^{3} / \mathrm{s}\right)$ at Marnay (a) and Meulan (b)

The first pattern, found for $\mathrm{NP}_{1} \mathrm{EC}$, shows a clear decrease of concentrations according to Seine River flow increase suggesting that the $\mathrm{NP}_{1} \mathrm{EC}$ comes from constant and punctual sources diluted by the Seine River. This hypothesis is reinforced by the increase of $\mathrm{NP}_{1} \mathrm{EC}$ concentrations according to the urbanization gradient as mentioned before. Therefore, $\mathrm{NP}_{1} \mathrm{EC}$ probably mostly originates from punctual urban sources such as WWTP effluents. While $\mathrm{NP}_{1}$ EC found at Meulan could originate from the urban sources of the Parisian conurbation, the concentrations found at Marnay are probably impacted by Troyes City (about 60,000 inhabitants) located about $50 \mathrm{~km}$ upstream of Marnay site. 
The second pattern, as reflected by the 4-NP and $\mathrm{NP}_{2} \mathrm{EO}$ trends, shows a decrease of concentration according to Seine River flow increase. However, this decrease of concentration is significantly less marked than the trend observed for $\mathrm{NP}_{1} \mathrm{EC}$. While the ratios between the highest and the lowest concentrations of $\mathrm{NP}_{1} \mathrm{EC}$ are about 14 and 10 respectively at Marnay and Meulan, the ratios for 4-NP do not exceed 3 at Marnay and 2 at Meulan. Thus, the influence of the punctual urban sources could be partially hide by the global contamination of the Seine River basin by 4-NP. This global contamination of the Seine River probably originates from the large uses of NPE since 1960 and the persistence of 4-NP in the environment. Consequently, the diffuse sources mentioned before (TAF and groundwater) as well as biodegradation of precursors $\left(\mathrm{NP}_{1} \mathrm{EC}, \mathrm{NP}_{1 \& 2} \mathrm{EO}\right.$ originate from urban sources) along the Seine River probably avoid high decreases of concentration according to hydrological conditions (lowest concentrations: $46 \mathrm{ng} / \mathrm{L}$ at Marnay and $73 \mathrm{ng} / \mathrm{L}$ at Meulan).

The last pattern, including $\mathrm{BPA}$ and $\mathrm{NP}_{1} \mathrm{EO}$, is difficult to interpret since the analytical variabilites of these two compounds are important and do not enable to draw any relationship between dissolved concentrations and Seine River flow. Therefore, it is impossible to conclude on the predominance of punctual urban sources or diffuse sources for BPA and $\mathrm{NP}_{1} \mathrm{EO}$. Nonetheless, in the case of BPA, the two highest concentrations at Meulan $(111 \mathrm{ng} / \mathrm{L}$ in January 2010 and $120 \mathrm{ng} / \mathrm{L}$ in July 2010) were found consecutively to rainy periods with large CSO discharges (January: 250,000 $\mathrm{m}^{3}$ dumped, July: 990,000 $\mathrm{m}^{3}$ dumped). Consequently, the wet weather urban sources such as CSOs or urban runoff discharged into the Seine River probably play a key role on short-term contamination of the Seine River by BPA.

\section{Conclusions}

This study aimed at investigating the APE and BPA in urban sources and evaluating the impact of a heavily urbanized area such as the Parisian conurbation on the receiving water. Hence, urban sources such as WWTP effluents, combined sewer overflows, urban runoff and total atmospheric fallout were studied. Depending on the urban sources considered, differences of concentrations and distribution patterns appear. WWTP effluents are featured by the predominance of NPE, especially $\mathrm{NP}_{1} \mathrm{EC}$, due to aerobic biological treatments of wastewater. No seasonal trend of concentration as well as no significant difference of concentration according to the biological treatment of wastewater was noticed. Only the effluent of WWTP4 (one of the biggest WWTP in the world) revealed higher concentrations of NPE and BPA due to lower efficiencies on carbon and nitrogen removals than the other WWTPs. Conversely, wet weather urban sources (CSOs and runoff) are dominated by BPA probably due to wastewater contribution and leaching of building materials.

In this study, a significant influence of the Parisian conurbation on $\mathrm{NP}_{1} \mathrm{EC}$ and $\mathrm{BPA}$ concentrations along the Seine River (respectively from $17( \pm 1) \mathrm{ng} / \mathrm{L}$ to $124( \pm 7) \mathrm{ng} / \mathrm{L}$ and from $20( \pm 7) \mathrm{ng} / \mathrm{L}$ to $66( \pm 23) \mathrm{ng} / \mathrm{L})$ was observed. For all other NPE, no significant evolution of concentrations from upstream to downstream sites was noticed suggesting that urban sources of 
the Parisian conurbation do not have major effect on receiving water and underlining the existence of diffuse sources at the scale of the Seine River basin. Finally, the variation of dissolved concentrations according to the Seine River flow at Meulan and Marnay sites exhibits the importance of spot urban sources for $\mathrm{NP}_{1} \mathrm{EC}$, and reinforces the hypothesis of the global dissemination of 4-NP at the scale of the Seine River basin. Unfortunately, the cases of BPA and $\mathrm{NP}_{1} \mathrm{EO}$ could not be interpreted because of their high analytical variabilities.

In order to better understand the homogeneity of 4-NP concentrations along the Seine River as well as the dynamic of NPE within the Seine River, a further study should be carried out to asses the biodegradation rates of these compounds in receiving water. Finally, the diffuse sources probably linked to river flow origins have to be clearly identified and better assessed in order to understand the widespread of NPE and BPA at the scale of the Seine River Basin.

\section{Acknowledgment}

This study was carried out within the framework of PIREN-Seine and OPUR research programs. Urban runoff was studied within the framework of the INOGEV French ANR project. The authors want to gratefully acknowledge the Parisian public sanitation service (SIAAP) and more especially Céline Briand and Jean Daste-Blanc for their helpful assistance for WWTP effluent and CSO samplings. The authors also want to thank Mohamed Saad, Cécile Mirande-Bret, Alex Segor, Philippe Dubois and Lila Boudahmane for their valuable assistances.

\section{References}

Ahel M, Giger W, Koch M (1994) Behaviour of alkylphenol polyethoxylate surfactants in the aquatic environment--I. Occurrence and transformation in sewage treatment. Water Res 28 (5):1131-1142

Bhattacharya H, Xiao Q, Lun L (2008) Toxicity studies of nonylphenol on rosy barb (Puntius conchonious): A biochemical and histopathological evaluation. Tissue Cell 40 (4):243-249

Björklund K, Cousins AP, Strömvall A-M, Malmqvist P-A (2009) Phthalates and nonylphenols in urban runoff: Occurrence, distribution and area emission factors. Sci Total Environ 407 (16):46654672

Bressy A, Gromaire MC, Lorgeoux C, Chebbo G (2011) Alkylphenol in atmospheric depositions and urban runoff Water Sci Technol 63 (4):671-679

Brian JV, Harris CA, Scholze M, Kortenkamp A, Booy P, Lamoree M, Pojana G, Jonkers N, Marcomini A, Sumpter JP (2007) Evidence of estrogenic mixture effects on the reproductive performance of fish. Environ Sci Technol 41 (1):337-344. doi:10.1021/es0617439

Brix R, Postigo C, Gonzalez S, Villagrasa M, Navarro A, Kuster M, de Alda MJL, Barcelo D (2010) Analysis and occurrence of alkylphenolic compounds and estrogens in a European river basin and an evaluation of their importance as priority pollutants. Anal Bioanal Chem 396 (3):1301-1309. doi:10.1007/s00216-009-3358-8

Cailleaud K, Forget-Leray J, Souissi S, Lardy S, Augagneur S, Budzinski H (2007) Seasonal variation of hydrophobic organic contaminant concentrations in the water-column of the Seine 
Estuary and their transfer to a planktonic species Eurytemora affinis (Calanoïd, copepod). Part 2: Alkylphenol-polyethoxylates. Chemosphere 70 (2):281-287

Cladiere M, Gasperi J, Gilbert S, Lorgeoux C, Tassin B (2010) Alkylphenol ethoxylates and bisphenol A in surface water within a heavily urbanized area, such as Paris. In: Marinov AM, Brebbia CA (eds) Water Pollution X, vol 135. WIT Transactions on Ecology and the Environment. Wit Press, Southampton, pp 131-142. doi:10.2495/wp100121

European Commission (2008) Directive 2008/105/EC of the European Parliament and of the Council of 16 December 2008 on environmental quality standards in the field of water policy, amending and subsequently repealing Council Directives 82/176/EEC, 83/513/EEC, 84/156/EEC, 84/491/EEC, 86/280/EEC and amending Directive 2000/60/EC of the European Parliament and of the Council. Official Journal of the European Union 348: 84-97

Gasperi J, Garnaud S, Rocher V, Moilleron R (2008) Priority pollutants in wastewater and combined sewer overflow. Sci Total Environ 407 (1):263-272. doi:10.1016/j.scitotenv.2008.08.015

Gasperi J, Gromaire MC, Kafi M, Moilleron R, Chebbo G (2010) Contributions of wastewater, runoff and sewer deposit erosion to wet weather pollutant loads in combined sewer systems. Water Res 44 (20):5875-5886. doi:10.1016/j.watres.2010.07.008

Giger W, Gabriel FLP, Jonkers N, Wettstein FE, Kohler H-PE (2009) Environmental fate of phenolic endocrine disruptors: field and laboratory studies. Philos Trans R Soc Lond, Ser A 367 (1904):3941-3963. doi:10.1098/rsta.2009.0148

Gilbert S, Gasperi J, Rocher V, Lorgeoux C, Chebbo G (2012) Removal of alkyphenols and polybromodiphenylethers by a biofiltration treatment plant during dry and wet-weather periods. Water Sci Technol 65 (9):1591-1598

Hohne C, Puttmann W (2008) Occurrence and temporal variations of the xenoestrogens bisphenol A, 4-tert-octylphenol, and tech. 4-nonylphenol in two German wastewater treatment plants. Environ Sci Pollut Res 15 (5):405-416. doi:10.1007/s11356-008-0007-2

Isobe T, Nishiyama H, Nakashima A, Takada H (2001) Distribution and behavior of nonylphenol, octylphenol and nonylphenol monoethoxylate in Tokyo metropolitan area: Their association with aquatic particles and sedimentary distributions. Environ Sci Technol 35 (6):1041-1049

John DM, White GF (1998) Mechanism for Biotransformation of Nonylphenol polyethoxylates to xenoestrogens in Pseudomonas putida. J Bacteriol 180 (17):4332-4338

Jonkers N, Knepper TP, De Voogt P (2001) Aerobic biodegradation studies of nonylphenol ethoxylates in river water using liquid chromatography-electrospray tandem mass spectrometry. Environ Sci Technol 35 (2):335-340

Jonkers N, Kohler HPE, Dammshauser A, Giger W (2009) Mass flows of endocrine disruptors in the Glatt River during varying weather conditions. Environ Pollut 157 (3):714-723. doi:10.1016/j.envpol.2008.11.029

Jonkers N, Sousa A, Galante-Oliveira S, Barroso CM, Kohler H-PE, Giger W (2010) Occurrence and sources of selected phenolic endocrine disruptors in Ria de Aveiro, Portugal. Environ Sci Pollut Res 17 (4):834-843. doi::10.1007/s11356-009-0275-5 
Latorre A, Lacorte S, Barcelo D (2003) Presence of nonylphenol, octyphenol and bisphenol a in two aquifers close to agricultural, industrial and urban areas. Chromatographia 57 (1-2):111-116. doi:10.1007/bf02497486

Loos R, Locoro G, Contini S (2010) Occurrence of polar organic contaminants in the dissolved water phase of the Danube River and its major tributaries using SPE-LC-MS2 analysis. Water Res 44 (7):2325-2335. doi:10.1016/j.watres.2009.12.035

Loyo-Rosales JE, Rice CP, Torrents A (2007) Fate of octyl- and nonylphenol ethoxylates and some carboxylated derivatives in three American wastewater treatment plants. Environ Sci Technol 41 (19):6815-6821. doi:10.1021/es070713i

Meybeck M, Lestel L, Bonte P, Moilleron R, Colin JL, Rousselot O, Herve D, de Ponteves C, Grosbois C, Thevenot DR (2007) Historical perspective of heavy metals contamination (Cd, Cr, $\mathrm{Cu}, \mathrm{Hg}, \mathrm{Pb}, \mathrm{Zn}$ ) in the Seine River basin (France) following a DPSIR approach (1950-2005). 375 (1-3):204-231. doi:10.1016/j.scitotenv.2006.12.017

Servos MR (1999) Review of the aquatic toxicity, estrogenic responses and bioaccumulation of alkylphenols and alkylphenol polyethoxylates. Water Qual Res J Canada 34 (1):123-177

Sharma VK, Anquandah GAK, Yngard RA, Kim H, Fekete J, Bouzek K, Ray AK, Golovko D (2009) Nonylphenol, octylphenol, and bisphenol-A in the aquatic environment: A review on occurrence, fate, and treatment. J Environ Sci Health, Part A: Environ Sci Eng 44 (5):423-442. doi:10.1080/10934520902719704

Staples CA, Dome PB, Klecka GM, Oblock ST, Harris LR (1998) A review of the environmental fate, effects, and exposures of bisphenol A. Chemosphere 36 (10):2149-2173

Vandenberg LN, Hauser R, Marcus M, Olea N, Welshons WV (2007) Human exposure to bisphenol A (BPA). Reprod Toxicol 24 (2):139-177

Vethaak AD, Lahr J, Schrap SM, Belfroid AC, Rijs GBJ, Gerritsen A, de Boer J, Bulder AS, Grinwis GCM, Kuiper RV, Legler J, Murk TAJ, Peijnenburg W, Verhaar HJM, de Voogt P (2005) An integrated assessment of estrogenic contamination and biological effects in the aquatic environment of The Netherlands. Chemosphere $59 \quad$ (4):511-524. doi:10.1016/j.chemosphere.2004.12.053

Vilain G, Garnier J, Passy P, Silvestre M, Billen G (2012) Budget of N2O emissions at the watershed scale: role of land cover and topography (the Orgeval basin, France). Biogeosciences 9 (3):1085-1097. doi:10.5194/bg-9-1085-2012

Voutsa D, Hartmann P, Schaffner C, Giger W (2006) Benzotriazoles, alkylphenols and bisphenol a in municipal wastewaters and in the Glatt River, Switzerland. Environ Sci Pollut Res 13 (5):333341. doi:10.1065/espr2006.01.295

Wetherill YB, Akingbemi BT, Kanno J, McLachlan JA, Nadal A, Sonnenschein C, Watson CS, Zoeller RT, Belcher SM (2007) In vitro molecular mechanisms of bisphenol A action. Reprod Toxicol 24 (2):178-198

Ying G-G, Williams B, Kookana R (2002) Environmental fate of alkylphenols and alkylphenol ethoxylates--a review. Environ Int 28 (3):215-226 
Zgola-Grzeskowiak A, Grzeskowiak T, Rydlichowski R, Lukaszewski Z (2009) Determination of nonylphenol and short-chained nonylphenol ethoxylates in drain water from an agricultural area. Chemosphere 75 (4):513-518. doi:10.1016/j.chemosphere.2008.12.022

Zhou HD, Huang X, Wang XL, Zhi XH, Yang CD, Wen XH, Wang QH, Tsuno H, Tanaka H (2010) Behaviour of selected endocrine-disrupting chemicals in three sewage treatment plants of Beijing, China. Environ Monit Assess 161 (1-4):107-121. doi:10.1007/s10661-008-0731-6 